\title{
STUDENTI S INVALIDITETOM U VISOKOM OBRAZOVANJU - POGLED IZ KUTA FORMALNE PODRŠKE
}

\section{STUDENTS WITH DISABILITIES IN HIGHER EDUCATION - THE PERSPECTIVE OF FORMAL SUPPORT SERVICES}

\author{
MARINA MILIĆ BABIĆ \\ Pravni fakultet, Sveučilište u Zagrebu, Zagreb, Hrvatska, kontakt: marina.milic.babic@pravo.hr
}

Primljeno/Received: 11. 04. 2020.

Prihvaćeno/Accepted: 03. 09. 2020.
Izvorni znanstveni rad / Original research article UDK: $378-056.26-057.875$

$364-787.7 / 8$

doi: $10.31299 /$ hrri.56.2.4
Sažetak: Visoko obrazovanje važan je segment pripreme za tržište rada svih studenata koji upisujući pojedini fakultet žele steći potrebnu edukaciju za rad u odabranom području. Zemlje Europske Unije, pa tako i Hrvatska, ulažu u razvoj visokog obrazovanja kroz različite operativne programe koji pridonose dostupnosti obrazovanja za sve kategorije građana. Otvorenost visokog obrazovanja svakom članu društva temelj je inkluzivne obrazovne politike Europske Unije. Obrazovne politike postaju područje interesa cijele europske zajednice jer se društvo znanja vidi kao temelj gospodarske konkurentnosti Europe na globalnom tržištu. Cilj je rada ispitati kako stručnjaci koji rade u službama podrške za studente s invaliditetom doživljavaju poštovanje prava na visoko obrazovanje studenata s invaliditetom na Sveučilištu u Zagrebu. Riječ je o kvalitativnom istraživanju povedenom u 2019. godini putem polustrukturiranih intervjua, dok su podaci obrađeni primjenom tematske analize. U istraživanju je sudjelovalo 10 stručnjaka koji rade u službama podrške za studente s invaliditetom na Sveučilištu u Zagrebu. Rezultati ukazuju na pozitivne primjere poštovanja prava na visoko obrazovanje, ali identificiraju i postojeće slabe točke koje je potrebno unaprijediti u skladu sa suvremenim postavkama inkluzivnog europskog društva. Promjene u budućnosti potrebne su u područjima standardizacije asistencije $i$ prijevoza, prilagodbe infrastrukture, redovite edukacije nastavnog osoblja, senzibilizacije studenata te u razvoju ljudskih resursa u uredima za studente s invaliditetom.

Ključne riječi: studenti s invaliditetom, pravo na visoko obrazovanje, formalna podrška

\begin{abstract}
Higher education plays a pivotal role in preparing students for the labour market by providing education at the university level required for work in the chosen field. The EU member states, including Croatia, invest in higher education through different operational programmes to increase access to education for all citizens. Equal access to higher education for all is at the core of EU education policies for inclusion. Moreover, the education policy importance rises on the European agenda as the concept of knowledge society becomes central to European competitiveness on the global market. This paper aimed to examine how professionals employed by support services for students with disabilities perceive the respect of the right to higher education for students with disabilities at the University of Zagreb. The paper is based on qualitative research from 2019, which involved semi-structured interviews and thematic analysis of data. The research included 10 professionals employed by the support services for students with disabilities at the University of Zagreb. Although the results indicated certain good practice examples of respecting the right to higher education, they also pointed out the challenges that ought to be addressed in line with contemporary inclusive practices in Europe. In the future, improvements are recommended in the following areas: standardising assistance and transportation, adapting infrastructure, continuing training of the teaching staff, raising student awareness and human resource development at the Office for Students with Disabilities.
\end{abstract}

Keywords: students with disabilities, right to higher education, formal support 


\section{UVOD}

Osoba s invaliditetom definira se kao osoba koja ima dugotrajna tjelesna, mentalna, intelektualna ili osjetilna oštećenja koja u međudjelovanju s različitim preprekama mogu sprečavati njezino sudjelovanje u društvu na ravnopravnoj osnovi s drugima (Zakon o profesionalnoj rehabilitaciji i zapošljavanju osoba s invaliditetom, 2018). Konvencija o pravima osoba s invaliditetom predstavlja prvi ugovor o univerzalnim ljudskim pravima koji izričito obvezuje države potpisnice na poduzimanje svih odgovarajućih mjera za eliminiranje diskriminacije na osnovi invaliditeta. Konvencija o pravima osoba $\mathrm{s}$ invaliditetom predstavlja dokument usmjeren prema promicanju i zaštiti prava osoba $\mathrm{s}$ invaliditetom. Upravo ova Konvencija osigurava osobama s invaliditetom koje su često žrtve diskriminacije, segregacije i marginalizacije, ravnopravno uživanje ljudskih prava, temeljnih ljudskih sloboda i poštovanje njihova dostojanstva vezano za sve aspekte života pa tako i pravo na visoko obrazovanje (Miličević, 2016). Unatoč činjenici da zakonima i pravilnicima nisu propisani oblici i načini pružanja prilagodbe za studente s invaliditetom, na što pravobraniteljica kontinuirano upozorava, zakonska osnova ipak postoji u Ustavu Republike Hrvatske (2014), Konvenciji o pravima osoba s invaliditetom (2008) i Zakonu o suzbijanju diskriminacije (2012) (Meić, 2014). Deklaracija o pravima osoba s invaliditetom (2005) naglašava nužnost uklanjanje prepreka za potpunu integraciju i sudjelovanje osoba s invaliditetom u društvenom, ekonomskom, kulturnom i političkom životu pod jednakim uvjetima koji vrijede i za sve druge građane. Potreba za podrškom studentima s invaliditetom tijekom studija izraženija je u situacijama kad se pojave problemi s polaganjem ispita i prolongiranjem studija te kod gubitka motivacije. Česte su situacije u kojima studenti s invaliditetom imaju probleme s polaganjem ispita i godinama bezuspješno pokušavaju završiti studij, pri čemu ne postoji ni služba ni savjetovanje koje bi im pomoglo da situaciju riješe i donesu odgovarajuće odluke. Pravobranteljica za osobe s invaliditetom u svom Izvješću iz 2019. ističe da: “(...) iako na sveučilištima postoje službe za podršku studentima s invaliditetom, nisu jasno definirane procedure pa je prilagodba često svedena na dogovor s profesorom. Prema iskustvu

\section{INTRODUCTION}

A person with a disability is defined as a person with permanent physical, mental, intellectual or sensory impairment, which, in interaction with different barriers, may hinder his or her participation in the society on an equal basis with others (Act on Professional Rehabilitation and Employment of Persons with Disabilities, 2018). The Convention on the Rights of Persons with Disabilities represents the first international consensus on universal human rights that explicitly binds signatory states to undertake relevant measures to eliminate discrimination based on disability. The Convention on the Rights of Persons with Disabilities equally serves as an instrument for the promotion and the protection of the rights of persons with disabilities. In particular, the Convention warrants full and equal enjoyment of human rights and fundamental freedoms to all persons with disabilities, who are otherwise particularly exposed to discrimination, segregation, and marginalisation. Furthermore, the Convention promotes respect for their inherent dignity in all aspects, including the right to higher education (Miličević, 2016). Although laws and regulations fail to stipulate the forms and the procedures for ensuring accommodations for students with disabilities - as continuously denounced by the Ombudswoman in Croatia - a relevant legal foundation nonetheless exists in the Constitution of the Republic of Croatia (2014), the Convention on the Rights of Persons with Disabilities (2008) and the Act on Combating Discrimination (2012) (Meić, 2014). The Declaration on the Rights of Persons with Disabilities (2005) further stresses the need to remove all barriers to full integration and participation of persons with disabilities in social, economic, cultural and political life on an equal basis with all other citizens. In particular, students with disabilities experience the need for support during their studies when they encounter difficulties in passing exams or extending their studies or when they lose motivation. Frequently, students face difficulties in passing the exams and finishing their studies for years without available counselling or services that would help them make relevant decisions to resolve their situation. The Ombudswoman for Persons with Disabilities states in her Report from 2019 that "although universities offer support services to stu- 
Pravobraniteljice, sveučilišta su načelno spremna za suradnju sa studentima s invaliditetom u pogledu osiguravanja prilagodbi i podrške. Međutim studenti su u najvećoj mjeri prepušteni autonomnim odlukama fakulteta, sveučilišta ili pak samih nositelja katedri. Pravna nesigurnost kojoj su izloženi studenti s invaliditetom rezultat je izostanka sustavne podrške, zakonske regulative i jasno definiranih procedura za procjenu načina i uvjeta osiguravanja potrebnih prilagodbi” (Izvješće Pravobraniteljice za osobe s invaliditetom, 2019: 125.)

Prema Izvješću o osobama s invaliditetom u Republici Hrvatskoj od 3.5.2019. u RH živi 511 281 osoba s invaliditetom od čega su 307647 muškarci (60\%) i 203634 žene (40\%) Tako osobe s invaliditetom čine oko 12,4\% ukupnog stanovništva RH. Oko $66 \%$ osoba s invaliditetom nema završenu osnovnu školu ili ima samo osnovnoškolsko obrazovanje. Oko 25\% ima srednju stručnu spremu dok je 3\% osoba s visokom ili višom stručnom spremom (Izvješće o osobama s invaliditetom u Republici Hrvatskoj, 2019). Najčešće su vrste oštećenja kod osoba s invaliditetom, na temelju Zakona o Hrvatskom registru o osobama s invaliditetom (2001), oštećenja lokomotornog sustava $(28,8 \%)$ te oštećenja drugih organa $(26,4 \%)$. Prema podacima Ureda za studente s invaliditetom (2020), na Sveučilištu u Zagrebu, na kojem studira oko 70 000 studenata, svega je oko 350 studenata s invaliditetom koji primaju neki od oblika potpore ili realiziraju prava putem svojega statusa, a ukupno je oko 400 evidentiranih studenata s invaliditetom na Sveučilištu u Zagrebu. Ustav Republike Hrvatske (2014), kao temeljni pravni akt, u članku 65. jamči svim svojim građanima dostupnost obrazovanja na svim razinama pod jednakim uvjetima te $u$ članku 57. ističe da država posvećuje posebnu skrb zaštiti osoba s invaliditetom i njihovu uključivanju u društveni život. UN-ova Konvencija o pravima osoba s invaliditetom (2008) najznačajniji je međunarodni dokument na području zaštite prava osoba $\mathrm{s}$ invaliditetom. Člankom 24. Konvencije jamči se osobama s invaliditetom pravo na obrazovanje bez diskriminacije i na osnovi jednakih mogućnosti, odnosno na ravnopravnoj osnovi s drugima. Zakon o znanstvenoj djelatnosti i visokom obrazovanju (2017) kao osnovni akt u sustavu visokog obrazovanja u članku 77. jamči ravnopravnost svih pri- dents with disabilities, relevant procedures are not clearly defined and the adjustments are often negotiated with individual professors. According to the Ombudswoman, universities nominally demonstrate their readiness to ensure adjustments and support for students with disabilities. However, students are most often left to the independent decisions of colleges, universities or heads of chairs. Students with disabilities face legal insecurity as a result of inconsistencies in support mechanisms, regulatory framework and definition of procedures for determining mechanisms and conditions for ensuring necessary adjustments" (Report of the Ombudswoman for Persons with Disabilities, 2019:125.)

According to the Report on Persons with Disabilities in the Republic of Croatia of 3 May 2019 , there are 511,281 persons with disabilities in Croatia, including 307,647 men (60\%) and 203,634 women (40\%). Accordingly, persons with disabilities represent $12.4 \%$ of the total population of Croatia. About $66 \%$ of persons with disabilities have not completed primary education or completed only primary education. Around 25\% have completed secondary education, whereas 3\% have higher education (Report on Persons with Disabilities in the Republic of Croatia, 2019). Based on the Act on the Croatian Register of Persons with Disabilities (2001), prevalent types of disability involve locomotor impairment (28.8\%) and impairment of other organs (26.4\%). According to the Office for Students with Disabilities (2020), among 70,000 students at the University of Zagreb, there are only around 350 students with disabilities who receive some type of assistance or enjoy different rights based on their status, as well as a total of 400 registered students with disabilities. As the founding legal act, the Constitution of the Republic of Croatia (2014), in Article 65, warrants access to education to all citizens and at all levels under equal conditions. Notably, Article 57 calls upon the state to ensure particular protection to persons with disabilities and their social inclusion. In addition, the United Nations (UN) Convention on the Rights of Persons with Disabilities (2008) represents the principal international instrument for the protection of persons with disabilities. In particular, Article 24 of the Convention warrants the right to education for persons with disabilities without discrimination 
stupnika prilikom postupka odabira pristupnika za upis na visoka učilišta, a u članku 88 , između ostalih studentskih prava, svim studentima osigurava pravo na kvalitetan studij i obrazovni proces kako je to predviđeno studijskim programom. Nadalje u članku 4. kao jedan od oblika diskriminacije osoba $\mathrm{s}$ invaliditetom navodi se propuštanje obavljanja razumnih prilagodbi sukladno specifičnim potrebama osoba s invaliditetom te se diskriminacijom smatra i propust da se osobama s invaliditetom, sukladno njihovim specifičnim potrebama, ne omogući korištenje javno dostupnih resursa, sudjelovanje $u$ javnom i društvenom životu, prilagodbom infrastrukture i prostora, korištenjem opreme i na druge načine.

\section{Studenti s invaliditetom u visokom obrazovanju}

Studenti s invaliditetom su svi studenti koji zbog bolesti ili oštećenja imaju teškoća u realizaciji svakodnevnih akademskih aktivnosti (Pravilnik o organizaciji i djelovanju Ureda za studente s invaliditetom Sveučilišta u Zagrebu, 2007). Reed, Kennett i Edmond (2015) proveli su istraživanje čiji rezultati pokazuju da studenti s invaliditetom koji upisuju sveučilište intrinzično motivirani željom za usvajanjem znanja i vještina iz područja koja su predmet njihovog interesa pokazuju veću akademsku snalažljivost i samoučinkovitost za razliku od studenata $\mathrm{s}$ invaliditetom koji upisuju fakultet motivirani vanjskim razlozima poput dobivanja boljeg posla ili ispunjavanja roditeljskih očekivanja. Shevlin, Kenny i Mcneela (2010) navode kako se visokoobrazovne institucije u Irskoj redovito potiču da omoguće kvalitetniji pristup i sudjelovanje ljudima iz marginaliziranih skupina koje su tradicionalno bili isključeni iz visokog obrazovanja, a koje uključuju i osobe s invaliditetom. Tako njihova istraživanja potvrđuju da studenti s invaliditetom navode arhitektonske barijere kao ozbiljne prepreke potpunom uključivanju. Isti autori zaključuju kako postoji niska razina svijesti o potrebama studenata $\mathrm{s}$ invaliditetom $\mathrm{u}$ visokom obrazovanju te da pozitivan stav osoblja fakulteta pridonosi boljoj prilagodbi fakultetske okoline. Kako bi proširili znanje o dostupnosti visokog obrazovanja studentima s invaliditetom, Sachs i Schreuer (2011) usporedile su studentska postignuća i iskustva and based on equal opportunities; that is, on an equal basis with others. Finally, as the main act on higher education in Croatia, the Act on Science and Higher Education (2017), in Article 77, guarantees equality to all candidates in the selection procedure for enrolment in higher education institutions. Among other student rights, in Article 88, it further stipulates the right to quality studies and education for all students, as defined by the study programme. Moreover, Article 4 defines the forms of discrimination of persons with disabilities, which may include failure to ensure reasonable accommodations, access to public resources or participation in public or social life, in line with the specific needs of persons with disabilities, through adaptation of space or infrastructure, equipment or in other ways.

\section{Students with disabilities in higher education}

Students with disabilities are all students who experience difficulties in daily academic activities due to illness or impairment (Regulation on Organisation and Activities of the Office for Students with disabilities at the University of Zagreb, 2007). In particular, research by Reed, Kennett, and Edmond (2015) revealed that students with disabilities demonstrated greater resourcefulness and self-efficacy in academic activities if they had been intrinsically motivated to enrol in universities by the desire to gain knowledge and skills in the field of their interest, in contrast to the students with disabilities who were extrinsically motivated by better career prospects and parents' expectations. Furthermore, Shevlin, Kenny, and Mcneela (2010) found that higher education institutions in Ireland were continuously encouraged to ensure better access and participation for marginalised groups, including persons with disabilities, who had traditionally been excluded from higher education. According to their research, students with disabilities noted architectural barriers as substantial obstacles to full inclusion. In light of a low general awareness of the needs of students with disabilities in higher education, the authors further observed that positive attitudes of the university staff fostered a friendlier university environment. To expand the knowledge base on access to higher education for students with disabilities, Sachs and Schreuer (2011) compared student performance 
tako da su u istraživanje uključile 170 studenata s invaliditetom na visokim učilištima u Izraelu i 156 studenata bez invaliditeta. Rezultati su pokazali da su akademska postignuća studenata $\mathrm{s}$ invaliditetom gotovo jednako visoka kao i postignuća studenata bez invaliditeta, a opća su iskustva studenata bila slična. Analiza podataka pokazuje da su studenti s invaliditetom uložili više vremena kako bi udovoljili zahtjevima svog studija, sudjelovali manje u društvenim i izvanfakultetskim aktivnostima te manje koristili računala i tehnologiju uopće.

\section{Oblici formalne podrške studentima s invaliditetom}

Studenti s invaliditetom imaju pravo prednosti pri upisu na studij. Kandidati sa $60 \%$ i više tjelesnog oštećenja imaju pravo upisa u statusu redovnih studenata izvan odobrene upisne kvote, ako nisu rangirani unutar odobrene kvote, pod uvjetom da prijeđu razredbeni prag i zadovolje na eventualnoj provjeri posebnih sposobnosti (Sveučilište u Zagrebu, 2020). Sveučilište u Zagrebu osiguralo je pomoćnu tehnologiju za potporu u studiranju studentima s oštećenjima vida i studentima sa specifičnim teškoćama u učenju. U okviru projekata nabavljena su sljedeća pomoćna pomagala: brajična bilježnica, brajični printer, elektronička povećala, džepni ručni skeneri, govorni kalkulatori, čitači ekrana, govorne jedinice i laptopi. Nadalje studenti koji se kreću uz pomoć kolica mogu podnijeti zahtjev za korištenjem usluge besplatnog prijevoza ZET-a prilagođenim kombijem, koju provodi Gradski ured za socijalnu zaštitu i osobe s invaliditetom Grada Zagreba (Gradski ured za socijalnu zaštitu i osobe s invaliditetom, 2017). Studenti s invaliditetom ostvaruju pravo na smještaj u studentskom domu (Pravilnik o uvjetima i načinu ostvarivanja prava redovitih studenata na subvencionirano stanovanje, 2019). Sveučilište u Zagrebu osigurava 24-satnu asistenciju studentima s težim oblicima motoričkih poremećaja smještenima u studentskim domovima "Stjepan Radić", "Dr Ante Starčević" i "Cvjetno naselje". Navedeni domovi imaju također i dijelove smještajnih kapaciteta prilagođenih studentima s invaliditetom kao i svi novoizgrađeni domovi izvan Zagreba poput domova u Čakovcu, Zadru, Splitu, Karlovcu, Osijeku, Varaždinu itd. Europska Unija i sve njezine države and experiences from 170 students with disabilities and 156 students without disabilities at higher education institutions in Israel. The results demonstrated that the academic performance of students with disabilities generally matched the performance of students without disabilities, as well as general student experiences. However, further data analysis revealed that students with disabilities invested more time to meet the demands of their studies, participated less in social and extra-curricular activities, and used computers and IT to a lesser extent.

\section{Types of formal support for students with disabilities}

Students with disabilities enjoy certain precedence in enrolment in higher education studies at the University of Zagreb. If they have not been ranked within the set enrolment quota, candidates with a minimum $60 \%$ physical impairment rating are entitled to enrol as regular students regardless of the enrolment quota, under the condition that they pass the examination benchmarks and the examination of additional competences if required (University of Zagreb, 2020). The University of Zagreb also ensures assistive technology to support students with visual impairment and students with specific learning disabilities. With project funding, the following assistive technology has been procured: Braille notebook, Braille printer, electronic magnifiers, pocket hand scanners, speech calculators, screen readers, speech units and laptops. Moreover, students in wheelchairs may request free local transportation by specialised vans from the City of Zagreb (Municipal Office for Social Welfare and Persons with Disabilities, 2017). Students with disabilities are also entitled to accommodation in student dormitories (Regulation on Conditions and Procedures for Exercising the Right of Regular Students to Subsidised Housing, 2019). The University of Zagreb provides 24-hour assistance for students with severe forms of motor impairment living in student dormitories "Stjepan Radić", "Dr Ante Starčević" and "Cvjetno naselje". These dormitories also feature accommodation units adapted to students with disabilities, as do all recently constructed dormitories outside Zagreb, including dormitories in Čakovec, Zadar, Split, 
članice potpisnice su Konvencije Ujedinjenih naroda o pravima osoba s invaliditetom. Taj je važni ugovor za EU stupio na snagu u siječnju 2011. te je odredio sadržaj Europske strategije za osobe s invaliditetom 2010.-2020. (Europska strategija za osobe s invaliditetom 2010.-2020., 2011). Od 26. listopada 2016. godine, na snazi je Direktiva (EU) 2016/2102 Europskog parlamenta i Vijeća o pristupačnosti internetskih stranica i mobilnih aplikacija tijela javnog sektora. Kao način potpore studentima s invaliditetom, Europska Unija financira sveučilišne školarine i financijsku pomoć studentima s invaliditetom (Službene internetske stranice Europske Unije, 2020). Što se tiče stipendija Ministarstvo znanosti i obrazovanja raspisuje dva javna natječaja za dodjelu državnih stipendija: 1. Natječaj za dodjelu 10000 državnih stipendija za akademsku godinu 2019/2020. redovitim studentima visokih učilišta u Republici Hrvatskoj i 2. Natječaj za dodjelu 400 državnih stipendija za posebne skupine studenata za akademsku godinu 2019/2020. redovnim studentima visokih učilišta u Republici Hrvatskoj, u okviru kojeg je 70 stipendija namijenjeno studentima osobama s invaliditetom (Ministarstvo znanosti i obrazovanja, 2019). Sveučilište u Zagrebu svake akademske godine raspisuje natječaj za stipendiranje studenata i Grad Zagreb također svake godine raspisuje poseban natječaj za dodjelu stipendija studentima s invaliditetom (Grad Zagreb, 2017). Uz navedene, oblike podrške pri Sveučilištu u Zagrebu dijele i Ured za studente s invaliditetom kao središnje koordinacijsko tijelo za formalne oblike podrške studentima, dok je na pojedinim sastavnicama uspostavljena uloga koordinatora za podršku studentima s invaliditetom. U većim sveučilišnim gradovima djeluju i udruge za studente s invaliditetom koje pružaju specifične oblike formalne podrške u skladu s individualnim potrebama pojedinih studenata.

\section{CILJ ISTRAŽIVANJA I ISTRAŽIVAČKA PITANJA}

Cilj ovog rada bio je ispitati kako stručnjaci koji rade u službama podrške za studente s invaliditetom doživljavaju poštovanje prava na visoko obrazovanje studenata s invaliditetom na Sveučilištu u Zagrebu.
Karlovac, Osijek, and Varaždin. The European Union (EU) and all its member states are signatories of the UN Convention on the Rights of Persons with Disabilities. This fundamental agreement for the EU entered into force in January 2011 and set the direction for the European disability strategy 2010-2020 (European Disability Strategy 2010-2020, 2011). Furthermore, Directive (EU) 2016/2102 of the European Parliament and of the Council on the accessibility of the websites and mobile applications of public sector bodies dates from 26 October 2016. The European Union allocates funding for university tuition and financial aid to support students with disabilities (official website of the European Union, 2020). Concerning scholarships, the Ministry of Science and Education announced two open calls for the award of state scholarships: (1) an open call to award 10,000 state scholarships in the academic year 2019/2020 to regular students of higher education institutions in the Republic of Croatia, and (2) an open call to award 400 state scholarships to special groups of students in the academic year 2019/2020 to regular students of higher education institutions in the Republic of Croatia, with the latter allocating 70 scholarships to students with disabilities (Ministry of Science and Education, 2019). Each academic year, the University of Zagreb announces a call for student scholarship awards, and the City of Zagreb publishes a special call for the award of scholarships to students with disabilities (City of Zagreb, 2017). In addition to the aforementioned types of support at the University of Zagreb, the Office for Students with Disabilities acts as the central coordinating body for formal types of support to students, while the individual units of the university appoint coordinators for support to students with disabilities. Moreover, associations for students with disabilities are present in major university towns and provide specific types of formal support based on the individual needs of students.

\section{RESEARCH AIM AND RESEARCH QUESTIONS}

This paper aimed to examine how professionals employed by support services for students with disabilities perceive the respect of the right to higher education for students with disabilities at 
Slijedom navedenog cilja u ovom istraživanju postavljena su sljedeća istraživačka pitanja:

1. Kako sudionici istraživanja doživljavaju poštovanje prava na visoko obrazovanje studenata sa invaliditetom na Sveučilištu u Zagrebu?

2. Koje teškoće/izazove za studente s invaliditetom sudionici istraživanja doživljavaju kao dominantne unutar postojećeg sustava visokog obrazovanja?

3. Koje promjene sudionici istraživanja doživljavaju kao nužne u budućnosti kako bi se studentima s invaliditetom omogućilo kvalitetnije visoko obrazovanje?

\section{METODOLOGIJA ISTRAŽIVANJA}

\section{Sudionici istraživanja}

Ciljana populacija koja je obuhvaćena ovim istraživanjem jesu stručnjaci koji rade u službama podrške za studente s invaliditetom na Sveučilištu u Zagrebu. Od stručne službe Sveučilišta u Zagrebu dobiven je popis koordinatora službe podrške za studente s invaliditetom na 30 sastavnica. Poziv je putem e-maila upućen svakoj sastavnici s liste, neke sastavnice nisu bile u mogućnosti sudjelovati zbog bolovanja ili službenog putovanja/odsutnosti nadležne osobe u vrijeme istraživanja. U konačnici u istraživanju je sudjelovalo 10 sudionika. Uzorak je sastavljen od ključnih informatora koji predstavljaju stručnjake bogate iskustvom i informacijama o predmetu istraživanja. Prosječna dob sudionika je 41,6 godina, dok je prosječni radni staž 17 godina. Raspon godina provedenih u službi podrške studentima s invaliditetom u prosjeku iznosi 6,5 godina.

\section{Metoda i postupak prikupljanja i analize podataka}

S obzirom na cilj istraživanja odabran je kvalitativni pristup. Istraživanje je započelo slanjem e-maila s pozivom na sudjelovanje $u$ istraživanju $u$ kojem su pojašnjeni svrha i cilj istraživanja. Zatim je definiran termin i lokacija provedbe intervjua. Prostor je bio prilagođen željama sudionika istraživanja tako da je istraživanje provedeno u uredima sudionika u terminima koji su im odgovarali. Sudionicima je zajamčena dobrovoljnost i povjerljivost podataka te anonimnost te je tražena njihova suglasnost za snimanje intervjua diktafonom. the University of Zagreb. The following research questions were defined for the present research:

1. How do research participants perceive the respect of the right to higher education for students with disabilities at the University of Zagreb?

2. Which difficulties/challenges for students with disabilities do research participants perceive as prevalent in the present higher education system?

3. Which interventions do research participants perceive as critical for improving the quality of higher education for students with disabilities in the future?

\section{METHODOLOGY}

\section{Research participants}

The research target population included professionals employed by support services for students with disabilities at the University of Zagreb. The University of Zagreb administration provided a list of coordinators of the support services for students with disabilities at 30 units. The invitation was sent to each unit from the list via e-mail; some could not participate due to sick leave or business travel/leave of relevant employees at the time of the research. Finally, 10 professionals were selected to participate in the research. The sample comprised key sources of information represented by professionals with extensive experience and knowledge on the research topic. The average participant age was 41.6 years, with an average of 17 years of professional experience. The extent of experience in support services for students with disabilities averaged 6.5 years.

\section{Methods of data collection and analysis}

The qualitative approach was chosen in line with the research aim. The research started with e-mail invitations to prospective participants, which explained the purpose and aim. Interview dates and locations were agreed next. Interview arrangements conformed to participant preferences: the interviews took place in their offices and at the time that was convenient for participants. They were assured of the voluntary disclosure and confidentiality of data, as well as their anonymity. 
Za potrebe prikupljanja empirijske građe korišten je polustrukturirani intervju, prema osmišljenom istraživačkom protokolu. Prosječno trajanje intervjua bilo je 38 minuta. Istraživanje je provedeno u 2019. godini. Dobiveni podaci obrađeni su postupkom tematske analize. Postupak je započeo višestrukim čitanjem transkripta od strane tri istraživača, odvajanjem odgovora relevantnih za cilj istraživanja $i$ istraživačka pitanja te sumiranjem individualnih analiza. $U$ cilju zaštite povjerljivosti sudionika istraživanja, izjave sudionika označene su rednim brojevima od 1 do 10 .

\section{REZULTATI I RASPRAVA}

Rezultati su prikazani kroz tri kategorije predviđene istraživačkim tematskim okvirom: 1) poštovanje prava na visoko obrazovanje mladih s invaliditetom, 2) izazovi/teškoće za studente $\mathrm{s}$ invaliditetom u sustavu visokog obrazovanja i 3) identificiranje potrebnih pozitivnih promjena $\mathrm{u}$ budućnosti. Navedene teme opisane su kroz kategorije i pojmove koji su u daljnjem tekstu nadopunjeni izjavama sudionika istraživanja.

\section{Poštovanje prava na visoko obrazovanje mladih $s$ invaliditetom}

Tablica 1. Kako sudionici istraživanja doživljavaju poštovanje prava na visoko obrazovanje mladih sa invaliditetom?

Sudionici istraživanja doživljavaju poštovanje prava na visoko obrazovanje mladih s invaliditetom unutar Sveučilišta u Zagrebu i njegovih sastavnica kroz poštovanje prava na informacije unutar čega se navodi kako mladi s invaliditetom imaju pravo na pristup informacijama preko obavijesti na mrežnim stranicama fakulteta: “...objavljujemo ključne informacije na web stranici fakulteta, pa studenti s invaliditetom imaju redovite i dostupne info..." (S9). Knott i Taylor (2014.) navode da su potrebne promjene i da institucije visokog obrazovanja trebaju biti aktivnije u plasiranju dostupnosti svih potrebnih informacija studentima s invaliditetom. Ističe se važnost infomiranosti još tijekom srednje škole i specifično organiziranim sveučilišnim danima otvorenih vrata i sajmovima zapošljavanja Mortimore (2013). Sudionici navode kako mladi s invaliditetom mogu prikupiti informacije na stra-
Participants' consent was also requested to record the interviews with a digital voice recorder. Based on the research protocol, semi-structured interviews were used to collect empirical data. The average interview duration was 38 minutes. The research was conducted in 2019. Data processing relied on thematic analysis. This involved an initial multiparty reading of the interview transcripts by three researchers, identification of answers relevant to the research aim and the research questions, as well as the summary of individual analyses. To ensure confidentiality, participant statements were marked by ordinal numbers from 1 to 10 .

\section{RESULTS AND DISCUSSION}

Results are presented through three themes as defined by the thematic framework of the research: 1) respect of the right to higher education for young people with disabilities; 2) challenges/difficulties for students with disabilities in the higher education system; and 3) identification of the necessary interventions for the future. The aforementioned themes were further elaborated through categories and codes and complemented by participants' statements as presented below.

\section{Respect of the right to higher education for young people with disabilities}

Research participants perceived the respect of the right to higher education for young people with disabilities at the University of Zagreb and its units as the respect of the "right to information", referring to the availability of "notifications at the university website" for young people with disabilities: "...We post key information at the university website, so students with disabilities have regular information available..." (S9). In this respect, Knott and Taylor (2014) called for a change and a greater engagement of higher education institutions in the dissemination of information to students with disabilities. Dissemination of information to secondary schools was also suggested, for example, by organising university open doors events and employment fairs (Mortimore, 2013). Participants equally mentioned that young people with disabilities could find the "information at the website 'Postani student' ('Become a student'): “...website 
Tablica 1. Kako sudionici istraživanja doživljavaju poštovanje prava na visoko obrazovanje mladih sa invaliditetom? / Table 1. How do research participants perceive the respect of the right to higher education for young people with disabilities?

\begin{tabular}{|c|c|}
\hline \multicolumn{2}{|c|}{ THEMATIC AREA: Respect of the right to higher education for young people with disabilities } \\
\hline Category & Codes \\
\hline \multirow[t]{4}{*}{ Right to information } & Notifications at the college website \\
\hline & Information at the website "Postani student" ("Become a student") \\
\hline & Orientation session presenting the formal support service \\
\hline & Guidance on rights and opportunities through counselling with the coordinator at the university unit \\
\hline Right to accommodation & Available capacities of student dormitories \\
\hline Right to transportation & Provision of transportation \\
\hline \multirow{5}{*}{$\begin{array}{l}\text { Right to modification } \\
\text { of academic terms and } \\
\text { conditions }\end{array}$} & Extended time for examination \\
\hline & Enlarged font \\
\hline & Adjustment of working and studying materials \\
\hline & Allocation of extended time for exam preparation \\
\hline & Alternative assignments to compensate for omitted ones \\
\hline \multirow{4}{*}{$\begin{array}{l}\text { Right to adaptations } \\
\text { in the academic } \\
\text { environment }\end{array}$} & Adapted infrastructure \\
\hline & Assistive devices for students with visual impairment \\
\hline & Organisation of education assistance \\
\hline & Moderated enrolment criteria in line with the degree of impairment \\
\hline \multirow{4}{*}{$\begin{array}{l}\text { Right to formal support } \\
\text { at the university and its } \\
\text { unit }\end{array}$} & Access to Ombudswoman for persons with disabilities \\
\hline & Access to the Office for Students with Disabilities at the University \\
\hline & Access to formal support coordinator \\
\hline & Availability of optional university courses for peer support \\
\hline
\end{tabular}

nici Postani student: “... dobra je i web stranica Postani student...” (S9). Osim dostupnih informacija na mrežnim stranicama mladima su dostupne informacije putem uvodnog predavanja na fakultetu na kojem se predstavi služba formalne podrške: "Obično krećemo od nekog uvodnog predavanja za brucoše gdje se ukratko predstavimo ili ja osobno ili me predstavi tamo netko od izlagača na samom predavanju. Znači predstavim se ukratko, tko mi se može obratiti, što im ja mogu ponuditi, tako da od prvog dana krećemo s informiranjem o dostupnoj podršci..." (S9). Također mladi s invaliditetom imaju mogućnost informiranja o pravima i mogućnostima na konzultacijama kod koordinatorice za podršku studentima s invaliditetom: “...informacija ide prema brucošima" "Dolaskom na konzultacije kod mene ja ih upoznajem s mogućnostima" (S8).

Nadalje sudionici istraživanja navode kako se poštuje i pravo na smještaj kroz dostupne smještajne kapacitete u studentskim domovima u sklopu obnove studentskih domova: “...uredio se Dom Cvjetno i uredio se Dom Stjepan Radić, što se tiče kapaciteta soba, mislim da su dobri..." (S10). Studentski centar Sveučilišta u Zagrebu ima uku-
Postani student is also useful..." (S9). Besides the information available on websites, young people also received relevant information during the "orientation session at colleges presenting the formal support service": "We usually start with the freshmen orientation session where we briefly introduce ourselves, either I or one of the presenters introduces me in the session. In other words, I briefly introduce myself, explain who may reach out to me, what I can offer; this way, we start informing about the available support from the very first day..." (S9). Furthermore, young people with disabilities could receive "guidance on the rights and opportunities through counselling with the support coordinator for students with disabilities": “...the information goes out to freshmen", "Through counselling, I present them the opportunities" (S8).

Additionally, research participants confirmed that the "right to accommodation" was respected given the available accommodation capacities of student dormitories and their reconstruction: “... The dormitories Cvjetno and Stjepan Radic have been refurbished, in terms of room capacities, I find them satisfactory..." (S10). The University Centre 
pno 31 sobu prilagođenu studentima koji se kreću uz pomoć invalidskih kolica i šest soba prilagođenih studentima koji se otežano kreću (Ćirić i sur., 2013). Poštuje se pravo na prijevoz. Iako mladi s invaliditetom slabo koriste usluge: "Molimo popis studenata koji su zainteresirani za prijevoz... i onda od ne znam, 30 i nešto studenata koliko ih ja imam tu, javi se dvoje, da im treba ZET-ov prijevoz" (S5). Ipak, oni koji se odluče na korištenje usluge nastoji im se osigurati prijevoz: "Imamo udrugu Zamisli koja sa studentima koji se odluče na to sklapa ugovore i onda s njima dogovara prijevoz..." (S1). Međutim dostupnost prijevoza je relativna. U Gradu Zagrebu postoji organizirani prijevoz ZET-a u obliku specijalnih kombija, no važno je napomenuti da je on namijenjen samo studentima koji se kreću pomoću invalidskih kolica (Gregov, 2016). To znači da je značajan dio studenata $s$ invaliditetom ovime isključen i ovisi o privatnom prijevozu. Pozitivna praksa u pogledu prijevoza za studente s invaliditetom vidljiva je na Sveučilištu Bournemouth gdje je student razvio aplikaciju za pametne telefone koja pomaže osobama u invalidskim kolicima da lakše pronađu adekvatna vozila (Bournemouth University, 2013). Osim prava na informacije sudionici navode kako mladi s invaliditetom imaju pravo na prilagodbu akademskih uvjeta/pravila iz čega proizlazi pravo na produženo vrijeme pisanja ispita: "Tako je, osigurava se adekvatna prilagodba kako bi imali jednake uvjete kao i ostali. Jer ako je netko slabovidan naravno da, recimo ima slabovidnih studenata kojima samo više vremena treba..." (S9), prilagodba materijala za rad i učenje: “... studenti su mi sami dali pozitivan feedbeck - da su profesori oko toga susretljivi, nastoje im gradivo koliko mogu prilagoditi, povećati tekstove, po potrebi poslati mailom i drugo u skladu s individualnim potrebama studenta..." (S10). Koliko je prilagodba važna, pokazuju rezultati istraživanja u Irskoj u kojoj je velik porast broja upisanih studenata s invaliditetom na fakultet (s $2 \%$ na $6 \%$ između 2004. i 2012. godine) (European Commission, 2014). Studentima s invaliditetom osigurava se duže vremensko razdoblje za pripremanje ispita, ukoliko je potrebno: "Kad god sam nešto trebala profesore, u bilo kojem kontekstu da im se odgodi ispit, da im da mogućnost da to nauče, svi su bili susretljivi, nikakvih prepreka nije bilo." (S10) te im se zadaju zadaci kojima studenti of the University of Zagreb has 31 rooms adapted to students using wheelchairs and 6 rooms for students with reduced mobility (Ćirić et al., 2013). The "right to transportation" was equally respected. However, young people with disabilities seldom used the available service: "We ask for a list of students requesting transportation... and then, from about 30 students whom I assist, two people sign up for public transportation" (S5). Nonetheless, for those who opted for the service, "provision of transportation" was secured: "There is the association Zamisli [Imagine] that signs agreements with the students who opt for transportation and makes further arrangements..." (S1). Nonetheless, access to transportation seemed relative: although the City of Zagreb organised public transportation service by specialised vans, it was notably only available to students using wheelchairs (Gregov, 2016). This excluded a significant portion of students with disabilities who were thus dependent on private transportation. In this respect, the University of Bournemouth featured a good practice example of a student developing a smartphone application that allowed persons in wheelchairs to locate adequate vehicles more easily (Bournemouth University, 2013). Besides the right to information, the participants suggested that young people with disabilities had the "right to modification of academic terms and conditions", which included the right to "extended time for examination": "This is correct; the appropriate adjustments are in place so that they have equal chances as everyone else. Of course, when someone is visually impaired, for example, there are students with visual impairment, they only need a bit more time... " (S9); "adjustment of working and studying materials": “...I got positive feedback from students themselves - the professors were accommodating, they tried to adjust the content as much as possible, to enlarge the text, to send it by e-mail, if necessary, and everything else in line with the individual needs of students..." (S10). The importance of such adjustments was corroborated by research findings from Ireland, which demonstrated a significant growth in enrolment of students with disabilities in colleges; notably, from $2 \%$ in 2004 to $6 \%$ in 2012 (European Commission, 2014). Furthermore, students with disabilities were "allocated extended time for exam preparation, if necessary": "Whenever I asked the professors, in a different context, to postpone the examination, to 
mogu nadoknaditi propušteno: "Ako bi se dogodilo da na nekom kolegiju student ne može udovoljiti obavezama zbog tih prilagodbi, probamo izaći u susret na drugi način, recimo da nadoknadi gradivo kroz seminare ili neke projekte." (S9). Također moguće je rabiti alate učenja na daljinu kako bi se povećala dostupnost za sve studente, pogotovo one kojima je zbog životnih okolnosti stalna fizička prisutnost otežana ili onemogućena (Nacionalni plan za unaprjeđenje socijalne dimenzije visokog obrazovanja u Republici Hrvatskoj 2019-2021., 2018). Kao važan aspekt poštovanja prava mladih $\mathrm{s}$ invaliditetom u visokom obrazovanju, mladima $\mathrm{s}$ invaliditetom je osigurano pravo na prilagodbu akademske okoline. Pod navedenim se smatra kao jedan od važnijih faktora prilagođena infrastruktura: "Postavljene su rampe.." (S8). U istraživanju koje je provela Meić (2014), prema prikupljenim podacima 57 ustanova ima pristupačan ulaz, 38 ima lift, 31 ima pristupačan sanitarni čvor, dok nijedna ustanova nema taktilne crte vođenja za osobe s oštećenjem vida i za slijepe. 26 ustanova navelo je druge prilagodbe u smislu uklanjanja arhitektonskih barijera: nastava se nastoji organizirati u pristupačnom prostoru, postavljeni su rukohvati i pomične rampe. Nadalje sudionici u ovom istraživanju navode kako su studentima omogućena pomagala za studente s oštećenjem vida: "Imamo i dosta pomagala za studente s vidnim oštećenjima. U knjižnici imamo elektronska povećala, računalne programe..." (S9). Iako se studentima nastoje omogućiti pomagala, često se zanemaruju primjerice taktilne crte vođenja i upozorenja za osobe s oštećenjima vida koje se služe bijelim štapom (Španić, 2011). Važan aspekt podrške u obrazovnom sustavu je i organizacija obrazovne asistencije: “...pružamo podršku studentima pri osiguranju i provedbi obrazovne asistencije..." (S3). Ustanove visokog obrazovanja trebaju osigurati pomoćnu tehnologiju za studente sa specifičnim oštećenjima i obrazovne asistente (asistente u nastavi) za studente $\mathrm{s}$ invaliditetom kojima je takav oblik asistencije potreban (Ćirić i sur., 2013). Mlade se potiče na upis na visoka sveučilišta na način da su im olakšani uvjeti upisa s obzirom na postotak oštećenja: "Zatim svi kandidati koji imaju 60\% i veće tjelesno oštećenje mogu ostvariti pravo prednosti pri upisu." (S2). U sklopu visokog obrazovanja, mladima se omogućuje pravo na formalnu podršku allow them to study, they were accommodating, there were no objections." (S10) or to suggest "alternative assignments to compensate for omitted ones":

"When the student cannot meet course requirements despite the adjustments, we try to accommodate differently, to compensate for the assignment through papers or other projects. "' (S9). Moreover, distance learning tools were offered to increase access for all students, especially the ones whose life circumstances reduced or impeded physical access (National Plan for the Advancement of the Social Dimension in Higher Education in the Republic of Croatia $2019-2021,2018)$. Another important aspect of the rights of young people with disabilities in higher education, namely "the right to adaptations in the academic environment", was equally recognised. The "adapted infrastructure" was considered one of the most significant factors in that respect: "Ramps were installed..." (S8). The research study by Meić (2014) confirmed that 57 institutions had an accessible entrance, 38 had a lift and 31 an accessible toilet, whereas none of the institutions had tactile paving for the blind and visually impaired. Twentysix institutions also mentioned additional adaptations for removing architectural barriers: the classes were normally held in an accessible space, there were handrails and portable ramps. Moreover, research participants indicated the availability of "assistive devices for students with visual impairment": "There are several devices for students with visual impairment. The library features electronic magnifiers, computer programmes..." (S9). Although devices were generally available, tactile paving and signals are commonly overlooked for visually-impaired persons who used the white cane (Španić, 2011). The "organisation of education assistance" represented an important aspect of support in the education system: “...we offer support to students in arranging and providing education assistance..." (S3). Higher education institutions are solicited to ensure assistive technology for students with impairment, as well as education assistants (teaching assistants) for students with disabilities who require such a form of assistance (Ćirić et al., 2013). Additionally, "moderated enrolment criteria in line with the degree of impairment" might "encourage young people to enrol in higher education institutions": "I know that all candidates with a minimum $60 \%$ physical impairment rating are entitled to priority enrolment." (S2). In 
unutar Sveučilišta i sastavnice kroz dostupnost pravobraniteljice za osobe s invaliditetom: “....kao koordinator za studente s invaliditetom krećem od informiranja studenata da ja postojim, kažem koje su moje obaveze i što radim ovdje na faksu." (S9). Zatim dostupnost Ureda za studente s invaliditetom pri Sveučilištu: "Dam im kontakte Ureda za studente s invaliditetom..." (S9), dostupnost formalnog koordinatora za podršku: “...ostvarujem suradnju s Uredom pravobraniteljice, dogovaramo i zajedno surađujemo te studentima pokušavamo dati svoju stručnu podršku..." (S9) te im se pruža dostupnost sveučilišnog izbornog kolegija kojim se osigurava vršnjačka podrška: “... postoji kolegij svaki semestar za sve koji su zainteresirani, koji se nudi svim fakultetima gdje student koji studira zajedno sa studentom s invaliditetom pruža vršnjačku podršku ..." (S5).

\section{Izazovi/teškoće za studente s invaliditetom u sustavu visokog obrazovanja}

Sudionici navode da pitanje asistencije, odnosno neuređeno pitanje asistencije predstavlja izazove/teškoće za studente s invaliditetom u sustavu visokog obrazovanja: "Problem je asistencija koja nije riješena, to je nešto što nije sustavno riješeno jer zapravo nema niti jednog pravilnika o tome, ništa se ne govori o asistenciji..." (S4). U Engleskoj je 2010. Vijeće za financiranje visokog obrazova- higher education, young people have the "right to formal support at the university and its unit" through "access to Ombudswoman for persons with disabilities": “...as coordinator for students with disabilities, I start by informing students that I am there; I explain my responsibilities and my role here at college." (S9). Furthermore, there is "access to the Office for students with disabilities at the University": "I forward them the contact information of the Office for Students with Disabilities..." (S9); "access to formal support coordinator": “...I cooperate with the Office of the Ombudswoman; we make arrangements and collaborate to provide the students with our professional support..." (S9); as well as the "availability of optional university courses for peer support: “...each semester, there is a course at all colleges for anyone interested, where students offer peer support to students with disabilities with whom they study." (S5).

\section{Challenges/difficulties for students with disabilities in the higher education system}

Participants affirmed that the issue of "assistance", that is, of "unregulated assistance", presented challenges/difficulties for students with disabilities in higher education: "The problem lies in the assistance, which is not addressed on a system level; there are no regulations, there is nothing on assistance..." (S4). Conversely, in 2010, the Higher

Tablica 2. Koje teškoće/izazove za studente s in validitetom sudionici istraživanja doživljavaju kao dominantne unutar postojećeg sustava visokog obrazovanja? / Table 2. Which difficulties/challenges for students with disabilities do research participants perceive as prevalent in the present higher education system?

\begin{tabular}{|l|l|}
\hline THEMATIC AREA: Difficulties/challenges for students with disabilities in the higher education system \\
\hline Category & Codes \\
\hline Assistance & Unregulated assistance in higher education \\
\hline \multirow{5}{*}{ Transportation } & Unregulated transportation \\
\cline { 2 - 2 } & Insufficient number of vehicles \\
\cline { 2 - 2 } & Inadequate vehicles \\
\cline { 2 - 2 } & Insensitive drivers and inadequate stops \\
\hline Architectural barriers & Inaccessibility of colleges and inexistent standards for adaptation of college buildings \\
\hline \multirow{5}{*}{ Untrained teaching staff } & Uninformed teaching staff \\
\cline { 2 - 2 } & Unprepared teaching staff \\
\cline { 2 - 2 } & Insensitive teaching staff \\
\cline { 2 - 2 } & Lenience of professors concerning course requirements \\
\hline \multirow{5}{*}{$\begin{array}{l}\text { Insensitivity to diversity } \\
\text { frome environment }\end{array}$} & Presence of stereotypes and prejudices \\
\cline { 2 - 2 } & Insensitive students \\
\hline (Un)adapted literature & Insufficiently adapted education materials to the specific needs of students with disabilities \\
\hline
\end{tabular}


nja za osiguralo financiranje programa za podršku asistenciji za studente (European Commission, 2014). Postoje i teškoće po pitanju prijevoza: neuređeno pitanje prijevoza: "Prijevoz je nešto što isto nije riješeno od strane fakulteta." (S1), nedovoljan broj vozila: “...koliko znam da nema dovoljno. Mislim da oni imaju neka dva kombija koja voze na razini cijelog Zagreba...” (S4). Iako su osigurana vozila za studente s invaliditetom, postoje teškoće s neprikladnim vozilima: "Postoji još i ovaj ZET-ov prijevoz, međutim on je većini naših studenata neprimjeren." (S1). Također nedovoljna senzibiliziranost vozača $i$ neprilagođenost stanica predstavlja izazov, ali i teškoće mladima s invaliditetom: "Imamo niskopodne tramvaje u koje se ne može ući na svim stanicama. Ista stvar kod buseva, ili vozač ne izađe, ne spusti rampu i slično. Tako da ima problema i stvarno je puno napravljeno i unaprijeđeno, ali ima još nedostataka na kojima treba raditi." (S2). Slični rezultati proizlaze i iz istraživanja koje su provele Milić Babić i Dowling (2015) u kojem studenti navode kako prepreke za jednakost mogućnosti u sustavu visokog obrazovanja uključuju: fizičke prepreke, minimalnu prilagodbu zahoda, liftova, učionica $i$ spavaonica, neadekvatan prijevoz i financije, nedostatak svijesti i osjetljivosti kod vršnjaka u visokom obrazovanju te nedostatak literature. Iako se nastoje osigurati jednaki uvjeti za pristup obrazovnom sustavu infrastrukturna neprilagođenost jedan je od većih izazova za mlade s invaliditetom. To je vidljivo kroz nepristupačnost fakulteta i nepostojanje standarda za prilagođenost svih zgrada fakulteta: "Naš fakultet također nije pristupačan." (S1). Istraživanje provedeno na Sveučilištu u Zagrebu 2011. pokazuje da je prostorna pristupačnost relativno loša gotovo na svim sastavnicama, a prostorno su najnepristupačniji Stomatološki fakultet i Akademija dramske umjetnosti (Španić, 2011). Nadalje sudionici navode needuciranost nastavnog osoblja kao još jednu prepreku u visokom obrazovnom sustavu. Neinformiranost nastavnog osoblja predstavlja problem za mlade s invaliditetom u visokom obrazovanju: “...needuciranost nastavnika...". Tu se javlja i nepripremljenost nastavnog osoblja: “..to je nepripremljenost nastavnika..." (S1) i nesenzibiliziranost nastavnog osoblja: “... jer onda nemam problema sa svojim kolegama koji kažu 'ali ja imam samo pismeni
Education Funding Council for England secured funding support for student assistance programmes (European Commission, 2014). Furthermore, there were difficulties with "transportation", that is, with "unregulated transportation": "Transportation is equally not addressed by faculties. " (S1); "insufficient number of vehicles": "... as far as I am aware, there are not enough [vehicles]. I believe there are two vans for the entire Zagreb..." (S4). Although vehicles for students with disabilities existed, there were challenges with "inadequate vehicles": "There is public transportation; however, it is inadequate for the majority of our students" (S1). Moreover, "insensitive drivers and inadequate stops" presented further challenges and difficulties for young people with disabilities: "The low-floor trams do not allow entry from all stops. The same goes for buses; or the driver does not exit the vehicle to put down the ramp, etc. In that sense, there are still issues: although a lot has been achieved and improved, there are still challenges that should be addressed" (S2). Research by Milić Babić and Dowling (2015) exposed similar issues in terms of barriers to equality in higher education from the student perspective: physical barriers, minimal adaptations of toilets, lifts, classrooms and boarding room, inadequate transportation and financing, lack of awareness and insensitivity of peers, as well as a lack of literature. Although equal opportunities in access to education were on the agenda, the "architectural barriers" presented a major challenge for young people with disabilities. This was particularly reflected in the "inaccessibility of colleges and inexistent standards for adaptation of college buildings": "Our college is also inaccessible" (S1). Research conducted at the University of Zagreb in 2011 attested that the spatial accessibility of university units was relatively poor in general, and notably in the case of the Faculty of Dentistry and the Academy of Performing Arts (Španić, 2011). Furthermore, the participants identified "untrained teaching staff" as another issue in the higher education system. In that regard, "uninformed teaching staff" presented a challenge for young people with disabilities in higher education: “...untrained staff..." Additionally, "unprepared teaching staff” was equally detected: “....unprepared teachers..." (S1), as well as "insensitive teaching staff': “...then, I do not have issues with colleagues who say: "but I only give written exams, I won't do 
ispit, ja neću nekoga usmeno pitati'...” (S4). U istraživanju provedenom u Engleskoj prepreke su za studente bile sljedeće: nesvjesnost nastavnika o vrsti invaliditeta kod studenta i nevoljkost za razumnu prilagodbu (Kendall, 2016). U istraživanju provedenom u Kini rezultati pokazuju da nastavnici imaju pozitivna stajališta i spoznaje o pravima studenata s invaliditetom. Međutim nastavnici nemaju motivaciju, relevantna znanja, vještine i učinkovite strategije kojima bi se mogli koristiti pri pružanju pomoći studentima s invaliditetom (Zhang, Rosen, Cheng i Li, 2018). Dolazi i do popustljivosti profesora u zadovoljavanju obveza na kolegiju: "Imala sam specifične situacije s nastavnicima pa onda, kažem: 'Gledajte, ne možete dati studentu prolaznu ocjenu ako nema kompetencije, to je veliki problem.' Onda meni profesor kaže: 'Žao mi je takvog studenta, kako bih ja njega srušio kad je osoba s invaliditetom'..." (S5). Sljedeća kategorija koja se pojavljuje kao teškoća jest neosjetljivost okoline na različitosti. Iz navedenog proizlazi da postoje stereotipi i predrasude: “... to su ti stereotipi da su studenti s invaliditetom oslobođeni nekog dijela gradiva. Ima predrasuda, ima." (S1). Vickerman i Blundell (2010) navode pet ključnih područja koja bi se trebala unaprijediti kako bi se omogućili pristup i pravo na studiranje osobama s invaliditetom, a to su: potpora uvođenju pripremnih semestara, mogućnost visokih učilišta da pokrenu slobodne nastavne programe prilagođene individualnim potrebama i mogućnostima studenata $\mathrm{s}$ invaliditetom, dostupno redovito savjetovanje za studente s invaliditetom, institucionalna posvećenost razvoju usluga podrške i planiranju razvoja u profesionalnom smislu pojedinog studenta s invaliditetom. Nadalje neosjetljivost studenata također predstavlja izazov: "Koliko god se trudili da senzibiliziramo njihove vršnjake, to očito nije dovoljno i trebamo više...” (S1); “... studenti na primjer često puta mrtvi hladni prođu pokraj studenta $\mathrm{s}$ invaliditetom, a vide da treba pomoć s vratima, da treba nešto pridržati ali samo ignoriraju..." (S7). Studenti s invaliditetom imaju poteškoća sa socijalnom interakcijom, poput komunikacije s kolegama na fakultetu, što utječe na njihov dodatnu izolaciju od vršnjaka (Polo-Sanchez i López-Justicia, 2012). Kao posljednja kategorija, navodi se (ne) prilagođena literatura, odnosno neprilagođenost obrazovnih materijala specifičnim potrebama stu- oral exams..." (S4). In this respect, a research study from England identified the following obstacles for students: unfamiliarity of teachers with the type of students' disability and their unwillingness for reasonable adjustment (Kendall, 2016). A research study from China further found that teachers generally displayed positive attitudes and awareness of the rights of students with disabilities. However, teachers lacked motivation, knowledge, skills and effective strategies for providing support to students with disabilities (Zhang, Rosen, Cheng and Li, 2018). In some instances, the "lenience of professors concerning course requirements" was also observed: "...I had certain situations with teachers when I said: "Look, you cannot pass the student if he/she does not have the competences, this is a big problem". And then the professor replied: "I feel sorry for the student; how can I fail him/her as a person with disability..." (S5). The following category of difficulties was the "insensitivity to diversity from the environment". This implied the "presence of stereotypes and prejudices": "...these are the stereotypes that study requirements are waived for students with disabilities", "Yes; there are prejudices" (S1). Vickerman and Blundell (2010) propounded five key areas for advancement which could expand the access and the right to education for persons with disabilities, including support to the introduction of foundation courses, option for higher education institutions to adapt open teaching programmes to individual needs and possibilities of students with disabilities, availability of regular counselling for students with disabilities, institutional commitment to the development of support services and professional development planning for each student with disabilities. Moreover, "insensitive students" also caused concerns: "No matter how much we try to raise the awareness of their peers, it is clearly not sufficient and we need to [do it] more..." (S1); “... students, for example, often pass by the student with disabilities with total indifference, even though they could see that he/she needs help with the door, that they should hold something [for him/her]; yet, they simply ignore it..." (S7). In particular, students with disabilities faced difficulties in social interaction, such as communication with colleagues at the university, which further aggravated their isolation from peers (Polo-Sanchez and López-Justicia, 2012). The final category referred to "(un)adapted literature", 
denata s invaliditetom: “... problem na kojem stalno radimo ali nedovoljno je prilagodba literature..." (S6). Hrvatski savez slijepih posjeduje pomoćnu tehnologiju za studente s oštećenjima vida i osigurava potporu osobama s oštećenjima vida (Ćirić $i$ sur., 2013), no unutar visokog obrazovanja i dalje su prisutni primjeri izostanka prilagodbe literature, specifično za slijepe studente i studente s oštećenjima vida.

\section{Promjene u budućnosti s ciljem adekvatnije formalne podrške u visokom obrazovanju}

Prva od kategorija koja se javlja kao odgovor na ovo tematsko područje jest standardizacija asistencije koja se očituje kroz uspostavu sustavnih pravila o asistenciji: “... da bi trebalo na razini sveučilišta dakle dogovoriti i staviti kao obvezno jasne standarde asistencije, definirane kroz pravilnike ..." (S1). U prethodno provedenom istraživanju iz 2014. godine 74 ustanove kao mogući oblik prilagodbe i pomoći u nastavi navele su mogućnost prilagodbe načina ispitivanja i nastavnog procesa. 32 ustanove odgovorile su kako studentima s invaliditetom omogućavaju ili, ako se ukaže potreba, mogu omogućiti, pomoć asistenta, a 17 ih ima prilagođenu literaturu (Meić, 2014). Osim asistencije obrazovanje na daljinu može ponuditi smislenu alternativu za studente s invaliditetom. Fakulteti i sveučilišta imaju priliku omogućiti izvođenje kvalitetnih internetskih tečajeva za studente s invaliditetom; ali podaci pokazuju da ovakav način prilagodbe dovodi do većeg broja odustajanja od studiranja (Heindel, 2014.). Sudionici navode kako postoji potencijalni napredak u standardizaciji or "education materials insufficiently adapted to the specific needs of students with disabilities": “...it is an issue that we continuously address; however, there are not enough adaptations of literature .." (S6). The Croatian Blind Union owns assistive technology for students with visual impairment and offers support to visually impaired persons (Ćirić et al., 2013). Nevertheless, in higher education, there were still instances of literature not adapted for blind and visually impaired students.

\section{Future interventions for more adequate formal support in higher education}

"Standardising assistance" emerged as the first category in response to this thematic area, reflected in the need for "establishing consistent standards in assistance": "...clear standards should be defined for assistance at the university level and set as mandatory, specified by regulations..." (S1). In earlier research from 2014, 74 institutions indicated the possibility to adjust examination and teaching among the available forms of adjustment and assistance; 32 institutions reported that they designated, or could designate if necessary, assistants to students with disabilities, and another 17 institutions adapted literature (Meić, 2014). Besides assistance, distance learning could offer a meaningful alternative for students with disabilities. Although colleges and universities have the opportunity to provide quality online courses to students with disabilities, research shows such adjustments may also lead to higher rates of school-leaving (Heindel, 2014). Participants further suggested there was room for progress in "standardising

Tablica 3. Koje promjene sudionici istraživanja vide kao neophodne u budućnosti kako bi se studentima s invaliditetom omogućilo kvalitetnije visoko obrazovanje? / Table 3. Which interventions do research participants perceive as critical for improving the quality of higher education for students with disabilities in the future?

\begin{tabular}{|l|l|}
\hline THEMATIC AREA: Future interventions for improved quality of higher education \\
\hline Category & Codes \\
\hline Standardising assistance & Establishing consistent standards in assistance \\
\hline Standardising transportation & Establishing consistent standards in transportation \\
\hline Adapting infrastructure & Removing structural barriers and adapting institutions \\
\hline Training teaching staff & Consistent instruction of teaching staff \\
\cline { 2 - 2 } & Continuing training delivery \\
\hline Raising student awareness & Promoting student sensitivity to diversity \\
\hline $\begin{array}{l}\text { Human resource development in the } \\
\text { Office for Students with Disabilities }\end{array}$ & Increasing the number of employees in the Office for students with disabilities \\
\hline
\end{tabular}


prijevoza, odnosno uspostavi sustavnih pravila o prijevozu: "Bilo bi sjajno kad bi se moglo drugačije posložiti i organizirati standardi usluge prijevoza za sve studente na razini Sveučilišta u Zagrebu. Možda da vozi linija i kruži svakih pola sata, sat vremena." (S9). Iako u Gradu Zagrebu postoji usluga prijevoza studenata s invaliditetom, s obzirom na katkad promjenjiv raspored, "rupe" između predavanja, neplanirane konzultacije i ostale studentske obveze, ovakav je način prijevoza za neke studente s invaliditetom suviše krut i nepraktičan (Kiš-Glavaš, 2016). Također i u prilagodbi infrastrukture, to jest uklanjanje građevinskih prepreka i prilagodba institucija: "Trebalo bi staviti kao prioritet građevinske prepreke koje ne bi smjele biti prisutne ni u jednoj javnoj ustanovi, a kamoli na fakultetu." (S7). Nadalje otvara se prostor i za redovitu edukaciju nastavnog osoblja kroz sustavnu pripremu nastavnog osoblja: "Ali zapravo je ono što manjka sustavna priprema ..." (S1), “...provođenje redovitih edukacija za nastavno osoblje...": “... išli su ti seminari na koje smo se mi mogli odazivati... dobio si nekakav korpus znanja, o specifičnostima prilagodbe, recimo studenta koji su slijepi, slabovidni, s oštećenjima sluha, pa motoričke teškoće i psihičke teškoće... Evo to bi trebalo ponovo uvesti." “... to treba nekoliko puta tijekom akademske godine održavati tematske i specifične edukacije...” (S1). Iako postoje programi za edukaciju nastavnog i nenastavnog osoblja za osobe s invaliditetom, edukacija se gotovo isključivo odnosi na aktivnosti ostvarene kroz projekt TEMPUS. Manji postotak fakulteta provodi takve edukacije, njih $35 \%$, a njih $53 \%$ uopće ih ne provodi (Meić, 2014). Osim edukacije nastavnog osoblja potrebno je poraditi i na senzibilizaciji studenata preko rada na osjetljivosti studenata na različitosti: "Koliko god se trudili da ih senzibiliziramo, to očito nije dovoljno i trebamo više.” (S1); “... u našem društvu kroz osnovnoškolski i srednjoškolski sustav minimalno se radi na senzibilizaciji, a u visokom obrazovanju potpuno izostaje ta važna tema..." (S8). Studenti s invaliditetom navode kako se često u društvu vršnjaka znaju osjećati kao "smetnja". Bude im teško, zamorno i neugodno učestalo objašnjavati vršnjacima da im je potrebno npr. pružiti ruku, pomoći na stepenicama itd. (Stančić i sur., 2014). Sudionici istraživanja ističu potrebu za razvojem ljudskih resursa ureda za transportation", notably in "establishing consistent standards in transportation": "It would be great if it could be rearranged, to reorganise transportation service for all students at the University of Zagreb. Perhaps, if there was a circular line every half an hour or every hour" (S9). Although the City of Zagreb organises the transportation service for students with disabilities, it seems too inflexible and impractical for some students with disabilities given the occasional alteration of their schedule, time in between classes, unscheduled consultations and other student responsibilities (Kiš-Glavaš, 2016). Further room for improvement was equally identified in "adapting infrastructure", notably in "removing structural barriers and adapting institutions": "Structural barriers should be a priority; they should be removed from all institutions, particularly faculties" (S7). Moreover, further progress was requested for "continuing training of teaching staff" through "consistent instruction of teaching staff": "In fact, we miss consistent instruction..." (S1); "...continuing training delivery to teaching staff...": “...we were invited to participate in these seminars... one received a body of knowledge on different aspects of adjustment for students who were, for example, blind or had visual, hearing, motor or mental impairment... This should be reintroduced"; "...thematic, focused training should be offered several times in the course of the academic year..." (S1). Although there are training programmes on disabilities for teaching and non-teaching staff, the training is almost exclusively reserved for activities within TEMPUS projects. As a result, only a small number of faculties deliver such training (35\%), whereas 53\% do not offer similar training (Meić, 2014). Besides teacher training, further efforts are requested for "raising student awareness", notably for "promoting student sensitivity to diversity": "No matter how much we try to raise their awareness, it is clearly not enough and we need [to do it] more." (S1); “...our society does little to raise awareness during primary and secondary education, and this important subject is completely ignored in higher education ..." (S8). Students with disabilities mention they often feel like "a nuisance" in the company of their peers. They find it difficult, tedious and uncomfortable to repeat to their peers that, for example, they need a hand, or help on the stairs, (Stančić et al., 2014). 
studente s invaliditetom na način povećanja broja zaposlenih: “... Dakle tu bi trebalo malo nadograditi, njihove kadrovske kapacitete, da oni stignu sve pokriti i raditi edukacije...” (S1); “... Kako očekivati educirano nastavno osoblje, senzibilizirane studente i adekvatne druge uvjete studiranja ako Ured za studente s invaliditetom nema veći broj kadrovski dobro ekipiranih stručnjaka koji bi provodili razne mjere i lobirali za poboljšanje uvjeta studiranja..." (S10); Potrebno je i unaprijediti koordinaciju kroz poboljšanje međusobne suradnje unutar razlicitih resora: “....sustavi su nepovezani i ključno je ekipirati zaposlene u uredu za studente s invaliditetom kako bi koordinirali podršku na svim sastavnicama..." (S4). U istraživanju Redpath i suradnika (2013) rezultati pokazuju da bi trebala postojati mreža komunikacije koja potiče dijalog između svih strana koje su zainteresirane za dobrobit studenata, a student je u središtu rasprava i uključen u sve odluke. Zatim pozornost se mora posvetiti razvoju osoblja, posebno u pogledu mentalnog zdravlja te dugoročni cilj institucija treba biti razumna prilagodba i inkluzivno obrazovanje za sve.

\section{METODOLOŠKA OGRANIČENJA I PREPORUKE ZA DALJNJA ISTRAŽIVANJA}

Iako se tijekom provedbe intervjua vodilo računa o tome da se intervjui provedu na adekvatnim mjestima bez ometajućih faktora, tijekom provedbe nekih intervjua došlo je do ometanja (zvonjava mobitela, ulaska drugih osoba). Troje sudionika istraživanja ima relativno kratak staž u službi podrške studentima s invaliditetom (kraći od dvije godine) što je uzrokovalo poteškoće $u$ davanju adekvatnih i sadržajno valjanih odgovora. Naime dva su sudionika imala između 18 i 24 mjeseca radnog staža na ovim poslovima i jedan nepuna 24 mjeseca i kod identificiranja konkretnih prijedloga za unaprjeđenje sustava podrške dali su odgovor da nisu dovoljno u sustavu da bi naveli opsežnije prijedloge. Nadalje ovim istraživanjem obuhvaćeno je Sveučilište u Zagrebu, dok je za dobivanje potpune slike na razini cijele RH potrebno uključiti i druga sveučilišta u zemlji. Istraživanje su provodili studenti završne pete godine fakulteta, koji nemaju dovoljno iskustva u provođenju intervjua što je
Furthermore, research participants expressed the need for "human resource development in the Office for Students with Disabilities" in the form of "increasing the number of employees": "...Human resources should be increased, so they could cover everything and deliver training..." (S1); "...How can one expect trained teachers, aware students and adequate learning conditions when the Office for Students with Disabilities does not have adequate human resources to implement different measures and advocate for the improved learning conditions..." (S10). Coordination should be advanced through "improving collaboration between different actors": "...different structures are disconnected; it is crucial to staff the Office for Students with Disabilities appropriately so it could coordinate support at all units..." (S4). Research findings by Redpath et al. (2013) called for a network that would facilitate dialogue between parties interested in student wellbeing, with the student at the core of discussions and involved in decision-making. Finally, staff development deserved further attention, particularly in terms of mental health, with the long-term goal for institutions to ensure reasonable adjustment and inclusive education for all.

\section{METHODOLOGICAL LIMITATIONS AND RECOMMENDATIONS FOR FURTHER RESEARCH}

Although the arrangements had been in place to conduct the interviews in an adequate location and with minimal disturbance, some distractions occurred in the course of certain interviews (cell phone ringing, other persons entering the room). Three participants had relatively short professional experience of less than two years in support services for students with disabilities, which resulted in certain difficulties in providing adequate and relevant answers. Namely, two participants had between 18 and 24 months of professional experience in this position and one participant under 24 months; while formulating proposals for advancing the support system, these participants stated they did not have enough experience in the field to offer elaborate proposals. Furthermore, this research involved the University of Zagreb, whereas a thorough study at the national level would 
moguće utjecalo na bogatstvo dobivenih odgovora. U narednim istraživanjima bilo bi važno prikazati ovu temu iz dodatnih perspektiva: studenata s invaliditetom i nastavnog osoblja te drugih studenata na svim sveučilištima i veleučilištima u RH. Važno bi bilo istražiti koje su vrste invaliditeta najzastupljenije u visokom obrazovanju te koji su načini i prijedlozi za povećanje broja studenata s invaliditetom od strane kreatora politika.

\section{ZAKLJUČAK}

S obzirom na prethodno prikazane rezultate možemo zaključiti da postoje pozitivni aspekti poštovanja prava na visoko obrazovanje studenata s invaliditetom na Sveučilištu u Zagrebu, ali i da ima još prostora za unapređenje kako bismo mogli govoriti o kvalitetnoj inkluziji. Što se tiče područja poštovanja prava na visoko obrazovanje mladih s invaliditetom unutar Sveučilišta u Zagrebu, sudionici istraživanja istaknuli su pravo na informiranje koje je po njihovoj procjeni pravovremeno i na zadovoljavajućoj razini. Tu je i prilagodba izvršavanja studentskih obaveza koja se očituje u produženom vremenu pisanja ispita, prilagodbi materijala za rad i učenje (npr. povećani font), osiguravanju većeg vremenskog razdoblja za pripremanje ispita te zadavanju zadataka kojima studenti mogu nadoknaditi propušteno. Kada je riječ o infrastrukturi možemo zaključiti da je ista neujednačena po fakultetima i nije na zadovoljavajućoj razini. Tako imamo fakultete na kojima su ulazi, dvorane, sanitarni čvorovi te svi ostali sadržaji prilagođeni studentima s invaliditetom, dok kod većine to nije slučaj ili je riječ o djelomičnoj prilagođenosti. Rezultati upućuju na neuređenost $i$ kada je riječ o prijevozu za studente s invaliditetom te kod obrazovne asistencije. Najveći je problem prijevoza u tome što ne postoji dovoljan broj vozila kako bi ista svima bila na raspolaganju za pokrivanje dinamičnih rasporeda studentskih obveza na fakultetima. Isto tako problem je i u neprilagođenim stajalištima autobusa i tramvaja, ali i u neosviještenosti drugih ljudi i vozača koji često ne žele pomoći. Što se tiče obrazovne asistencije sudionici su naveli kako ona nije standardizirana. Kao jedna od teškoća za studente s invaliditetom unutar postojećeg sustava visokog obrazovanja navodi se i nastavno osoblje, točnije njihova nein- warrant the participation of other universities in Croatia as well. The interviews were conducted by senior college students who had limited experience, which might have influenced the quality of answers. Future research should further explore the topic from different perspectives, notably that of the students with disabilities, teaching staff and other students at all universities and polytechnics in Croatia. The prevalence of different disabilities among students in higher education would also be worth researching, as well as different interventions and recommendations from policy-makers for increasing the number of students with disabilities.

\section{CONCLUSION}

From the presented results, it may be derived that there are positive aspects of respecting the right to higher education of students with disabilities at the University of Zagreb, and equally that there is room for greater quality of inclusion. In terms of different aspects of the right to higher education for young people with disabilities, research participants stressed the provision of information that they found timely and satisfactory. Furthermore, modifications in academic requirements were equally highlighted, such as extended time for examination, adjustment of working and studying materials (e.g. enlarged fonts), allocation of extended time for exam preparation and alternative assignments for students to compensate for the omitted tasks. On the other hand, the level of infrastructure varied at different faculties and it was generally considered not satisfactory. In this respect, there were faculties with entrances, lecture halls, toilets or the entire facilities adapted to students with disabilities; however, this was not the case at most faculties, or faculties had only partial adjustments. The results revealed inconsistencies in transportation and education assistance for students with disabilities. An insufficient number of vehicles represented a substantial challenge for efficient transportation that would cater to a dynamic schedule of student responsibilities at the university. Likewise, inadequate bus and tram stops posed further challenges on top of insufficient awareness of drivers or other people who were generally seen as unwilling to help. Similarly, the participants found the provision of education assistance was inconsistent. Moreover, 
formiranost, nesenzibiliziranost i nepripremljenost koja zna rezultirati snižavanju kriterija za studente s invaliditetom pri zadovoljavanju akademskih ishoda. Stoga sudionici predlažu uvođenje edukacija za nastavno osoblje kako bi povećali svoj korpus znanja o specifičnostima prilagodbe za studente $\mathrm{s}$ invaliditetom. Zaključno ističu se promjene kroz povećanje broja zaposlenih u uredu za studente $\mathrm{s}$ invaliditetom te poboljšanje međusobne suradnje unutar različitih resora (zdravstvo, školstvo, tržište rada...). U daljnjim istraživanjima potrebno je dodatno uključiti i studente s invaliditetom kao i nastavno osoblje te ostale studente na različitim sveučilištima i veleučilištima diljem Hrvatske. uninformed, insensitive and unprepared teachers presented challenges for students with disabilities in higher education, including their occasional lenient attitude towards students with disabilities in achieving learning outcomes. For this reason, participants suggested the introduction of training and workshops for teachers to expand their understanding of different aspects of adjustment for students with disabilities. Finally, participants called for further employments in the Office for Students with Disabilities, as well as for an improved collaboration between different actors (e.g. health care system, education, labour market) Further research is recommended to encompass students with disabilities, teaching staff and other students at different universities and polytechnics across Croatia. 


\section{LITERATURA / REFERENCES}

Bournemouth University (2013). BU student develops mobile app to help wheelchair users get into cars, accessed on Bournemouth University website on 11.3.2020.: https://news.bournemouth.ac.uk/2013/08/07/bu-student-developsmobile-app-to-help-wheelchair-users-get-into-cars/.

Brinckerhoff, L. C., Shaw, S. F., and McGuire, J. M., (1992). Promoting Access, Accommodations, and Independence for College Students with Learning Disabilities. Journal of Learning Disabilities, 25,7, 417-429.

Ćirić, J., Divjak, B., Doolan, K., Farnell, T., Jedriško, D., Kiš-Glavaš, L., Laleta, S., Majstorović, I., Žižić, N., V., Šušak, I., and Vrbas, N. (2013). Osiguravanje minimalnih standarda pristupačnosti visokog obrazovanja za studente s invaliditetom u Republici Hrvatskoj [Ensuring minimal standards of accessibility for students with disabilities in higher education in the Republic of Croatia], Zagreb: University of Zagreb.

Deklaracija o pravima osoba s invaliditetom [Declaration on the rights of persons with disabilities], Official Gazette, No. $47 / 05$.

European Commission/EACEA/Eurydice (2014). Modernisation of Higher Education in Europe: Access, Retention and Employability 2014. Eurydice Report. Luxembourg: Publications Office of the European Union.

European disability strategy 2010-2020 (2011). Official Journal of the European Union.

City of Zagreb (2017). Stipendija Grada Zagreba za učenike i studente s invaliditetom [Scholarships of the City of Zagreb for pupils and students with disabilities], accessed on the website of the City of Zagreb on 7.3.2020.: https://www.zagreb.hr/stipendija-grada-zagreba-za-ucenike-i-studente-s-i/21164.

Municipal office for social welfare and persons with disabilities (2017). Gradski ured za socijalnu zaštitu i osobe s invaliditetom [Municipal office for social welfare and persons with disabilities], accessed on the website of the Municipal office for social welfare and persons with disabilities on 7.3.2020.: https://www.zagreb.hr/gradskiured-za-socijalnu-zastitu-i-osobe-s-invali/16814.

Gregov, B. (2016). Uključenost osoba s invaliditetom u visokoškolski obrazovni sustav [Inclusion of persons with disabilities in the higher education system], accessed on the website Voxfeminae on 9.3.2020.: https://voxfeminae. net/pravednost/ukljucenost-osoba-s-invaliditetom-u-visokoskolski-obrazovni-sustav-3/.

Heindel, A. J., (2014). A Phenomenological Study of the Experiences of Higher Education Students with Disabilities (doctoral dissertation). Florida: University of South Florida.

Izvješće o osobama s invaliditetom u Republici Hrvatskoj [Report on persons with disabilities in the Republic of Croatia] (2019). Zagreb: Croatian Public Health Institute: Public Health Service.

Izvješće pravobraniteljice za osobe s invaliditetom (Report of the Ombudswoman for persons with disabilities), (2019). accessed on the website 20.08.2020. https://posi.hr/wp-content/uploads/2020/04/Izvje\%C5\%A1\%C4\%87e-oradu-POSI-za-2019.pdf

Kendall, L. (2016). Higher education and disability. Exploring student experiences, 3(1).

Kiš-Glavaš, L. (2016). Smjernice za unapređenje sustava potpore studentima s invaliditetom u visokom obrazovanju u Republici Hrvatskoj [Guidelines for the advancement of support structures for students with disabilities in higher education in the Republic of Croatia], accessed on the website of the University of Zagreb on 9.3.2020.: http:// www.unizg.hr/fileadmin/rektorat/Studiji_studiranje/Podrska/SSI/Smjernice_LKG_2016.pdf.

Knott, F., and Taylor, A. (2014). Life at university with Asperger syndrome: A comparison of student and staff perspectives. International Journal of Inclusive Education, 18, 4, 411-4.

Convention on the rights of persons with disabilities (2008). Official Gazette, No. 6/2007, 3/2008, 5/2008.

Meić, B. (2014). Položaj osoba s invaliditetom u sustavu visokog obrazovanja - perspektiva ureda pravobraniteljice za osobe s invaliditetom [Position of persons with disabilities in the higher education system - the perspective of the Office of the Ombudswoman for persons with disabilities]. Jahr - European Journal of Bioethics, 5,1, 23-34. 
Miličević, J. (2016). Položaj osoba s invaliditetom u sustavu socijalne politike u Republici Hrvatskoj (Diplomski $\mathrm{rad}$ [Position of persons with disabilities in the social policy system in the Republic of Croatia (Master thesis)]. Zagreb: Faculty of Education and Rehabilitation Sciences.

Milić B., M., and Dowling, M. (2015). Social support, the presence of barriers and ideas for the future from students with disabilities in the higher education system in Croatia. Disability \& Society, 30,4, 614-629.

Ministry of Science and Education (2019). Natječaji [Calls], accessed on the website of the Ministry of Science and Education on 7.3.2020.: https://mzo.gov.hr/istaknute-teme/natjecaji-196/3147.

Mortimore, T. (2013). Dyslexia in higher education: Creating a fully inclusive institution. Journal of Research in Special Educational Needs, 13,1, 38-47.

Nacionalni plan za unaprjeđenje socijalne dimenzije visokog obrazovanja u Republici Hrvatskoj 2019. - 2021. [National plan for the advancement of the social dimension in higher education in the Republic of Croatia 2019 -2021] (2018). Zagreb: National task force for the advancement of the social dimension of higher education

Patton, M. Q. (2002). Two decades of developments in qualitative inquiry: A personal, experiential perspective. Qualitative Social Work: Research and Practice, 1,3, 261-283.

Polo-Sanchez, M., T., and López-Justicia, M., D. (2012). Autoconcepto de estudiantes universitarios con discapacidad visual, auditiva y motora. Revista Latinoamericana de Psicología, 44,2, 87-98.

Pravilnik o organizaciji i djelovanju Ureda za studente s invaliditetom Sveučilišta u Zagrebu [Regulation on organisation and activities of the Office for students with disabilities at the University of Zagreb] (2007). Accessed on the website of the University of Zagreb on 9.3.2020.: http://www.unizg.hr/fileadmin/rektorat/O_Sveucilistu/ Dokumenti_javnost/Propisi/Pravilnici/Pravilnik_Ured_za_studente_s_invaliditetom.pdf.

Pravilnik o uvjetima i načinu ostvarivanja prava redovitih studenata na subvencionirano stanovanje [Regulation on conditions and procedures for exercising the right of regular students to subsidised housing] (2019). Official Gazette, No. 63/2019.

Redpath, J., Kearney, P., Nicholl, P., Mulvenna, M., Wallace, J., and Martin S. (2013). A qualitative study of the lived experiences of disabled post-transition students in higher education institutions in Northern Ireland. Studies in Higher Education, 38,9, 1334-1350.

Reed, M., J., Kennett, D., J., and Emond M. (2015). The influence of reasons for attending university on university experience: A comparison between students with and without disabilities, Active Learning in Higher Education, $16,3,225-236$.

Sachs, D., and Schreuer, N. (2011). Inclusion of Students with Disabilities in Higher Education: Performance and participation in student's experiences, Disability Studies Quarterly, 31,2.

Shevlin, M., Kenny, M., and Mcneela, E. (2010). Participation in higher education for students with disabilities: an Irish perspective, Disability \& Society, 19,1, 15-30.

Official website of the European Union (2020). University fees and financial help, accessed on the official website of the European Union on 11.3.2020.:https://europa.eu/youreurope/citizens/education/university/fees-and-financialhelp/index_hr.htm.

Snyder, T., D., Hoffman, C., M., and Geddes, C., M. (1996). Digest of Education Statistics. U. S. Department of Education: National center for education statistics.

Stančić, Z., Kiš-Glavaš, L., Urbanc, K., Laklija, M., Milić Babić, M., and Vanja, B. (2014). Multidimenzionalna analiza socijalne uključenosti djece s teškoćama i studenata s invaliditetom u obrazovnom procesu [Multidimensional analysis of the social inclusion of children and students with disabilities in the education process]. Zagreb: Croatian Union of Persons with Hearing and Visual Impairment Dodir. 
University of Zagreb (2020). Oblici potpore studentima s invaliditetom na Sveučilištu u Zagrebu [Types of support for students with disabilities at the University of Zagreb], accessed on the website of the University of Zagreb on 7.3.2020.: http://www.unizg.hr/studiji-i-studiranje/podrska-studentima/podrska-studentima-s-invaliditetom/ oblici-potpore/.

Španić, D. (2011). Definicija pristupačnosti [Definition of accessibility]. In Haničar, E. (ed.); Studenti s invaliditetom: Prostorna pristupačnost [Students with disabilities: Spatial accessibility]. Zagreb: University of Zagreb.

Constitution of the Republic of Croatia (2014). Official Gazette, No. 56/1990, 135/1997, 08/1998, 113/2000, 124/2000, 28/2001, 41/2001, 55/2001, 76/2010, 85/2010, 05/2014.

Vickerman, P., and Blundell, M. (2010). Hearing the voices of disabled students in higher education. Disability \& Society, 25,1, 21-32.

Act on Croatian register of persons with disabilities (2001). Official Gazette, No. 64/01.

Act on professional rehabilitation and employment of persons with disabilities (2018). Official Gazette, No. 157/2013, $152 / 2014,39 / 2018$.

Act on science and higher education (2017). Official Gazette, No. 123/2003, 198/2003, 105/2004, 174/2004, 46/2007, 45/2009, 63/2011, 94/2013, 139/2013, 101/2014, 60/2015, 131/2017.

Zhang, Y., Rosen, S., Cheng, C., and Li, J. (2018). Inclusive Higher Education for Students with Disabilities in China: What Do the University Teachers Think? Higher Education Studies, 8,4, 104-115. 